Bangladesh J. Plant Taxon. 14(2): 101-115, 2007 (December)

\title{
CHARACTERISTICS OF THE PROXIMAL TO DISTAL REGIONS OF THE PETIOLES TO IDENTIFY 15 TREE SPECIES OF PAPILIONOIDEAE-FABACEAE
}

\author{
Samia Heneidak ${ }^{1}$ and Abdel Samai M. ShaheEN ${ }^{2}$ \\ Botany Department, Faculty of Applied Sciences, Suez Canal University, Suez, Egypt
}

Key words: Accessory ridge bundles, Crystals, Papilionoideae, Petiole anatomy, Petiole vasculature, Ridge bundles, Secretory cavities

\begin{abstract}
Comparative studies on the structure of the vascular supply of stem-leaf transitional zone of the petioles were carried out in 15 papilionoid tree species. Anatomical characteristics and changes in the main vascular trace were recorded. The anatomical features of significance include outline; epidermal cell; pericyclic fiber patterns; main petiolar vasculature; presence, number and separation of ridge vascular bundles; presence of additional accessory ridge bundles; crystal types; secretory elements and multicellular trichomes. Erythrina variegata and Pterocarpus indicus show no change in the petiole trace structure throughout their petioles from proximal to distal, while the rest of the species have minor to major changes. Sophora secundiflora has the highest number of ridge vascular bundles (5-6), while these are absent in the two Dalbergia species, E. variegata, Derris robusta, Sophora davidii and S. japonica. Only Derris robusta and Sophora japonica show unusual petiole trace structure by having two additional accessory ridge bundles adaxial of the main trace enclosing with it by a complete ring of pericyclic fibers. The studied species of tribe Millettieae show the presence of secretory cavities lined by epithelial cells. The usefulness of these character states is shown for assessing, identifying and delimiting these examined species.
\end{abstract}

\section{Introduction}

Papilionoideae is the biggest subfamily of the three widely recognized subfamilies of Fabaceae, and consists of 31 tribes (Polhill 1981, Mabberley 1997, Lewis et al. 2005). It contains approximately 426 genera and about 12,150 species distributed with greatest diversity in Brazil, Mexico, East Africa and Madagascar; and a few basic stocks in Mediterranean (Mabberley 1997).

Anatomical data have been used at all levels of taxonomic hierarchy as well as for identification and assessment of taxonomic relationships among the taxa of flowering plants (Stuessy 1990). Vesque (1885) studied a number of families and used petiole anatomy to separate genera and families formerly united. Subsequently, the study of petiole anatomy has received much attention and has provided many useful characters

${ }^{1}$ Corresponding author. E-mail: sheneidak2000@yahoo.com ${ }^{2}$ Botany Department, Aswan Faculty of Science, South Valley University, Egypt. E-mail: abdushaheen@yahoo.com 
(Watari 1934, Hare 1943, Metcalfe and Chalk 1950, Howard 1979, Al-Nowaihi et al. 1980, Khalifa and El Gohary 1982). Petiole anatomy has proved to be useful in the delimitation of the genera Musa (Ennos et al. 2000), Quercus (Maria and Rodriigo 2003), Cucurbita (Agbaywa and Noukwu 2004) and Ficus (Saquaro 2005).

Regarding the family Fabaceae (Leguminosae), Watari (1934) examined the vasculature of the petioles and leaves of 133 species of its three subfamilies. Of these, 96 species were from Papilionoideae, 12 from Mimosoideae, and 25 from Caesalpinioideae. Shaheen $(1995,2006,2007)$ studied the anatomy of the stem-leaf transitional zone of the petiole, and used the results to delimit and identify some species of mimosoid and caesalpinioid species. Taxonomically useful anatomical characters included pericyclic fiber patterns, main petiole trace types, number and position of secondary bundles and additional accessory bundles, as well as crystal and trichome types.

No comprehensive work has been done on petiole anatomy and their proximal to distal vascular supply in trees of the subfamily Papilionoideae. Thus, the present comparative anatomical investigation was carried out based on fresh samples from the proximal, medial and distal regions of the petioles of 15 papilionoid species to obtain a good guide and additional characters for the identification and delimitation of these important ornamental trees.

\section{Materials and Methods}

Fresh materials of mature petioles of 14 cultivated species of Papilionoideae was collected from Plant Island, Aswan, Egypt on 15 May 2006, while Sesbania sesban was collected from Aswan Faculty of Science, South Valley University, Egypt on the same day (Table 1). All the studied taxa are cultivated plants except Sesbania sesban, which is wild and cultivated. These species were identified by comparison with herbarium specimens kept at ASW Herbarium (Aswan Faculty of Science Herbarium, South Valley University, Egypt), and the herbarium of Plant Island, Aswan, Egypt. Herbarium specimens were prepared for all species from the collected fresh materials, and are deposited in the ASW Herbarium and Biological Sciences Department, Suez Faculty of Education, Suez Canal University, Egypt.

Three samples per species from different individuals and three petioles per sample were examined. Petiole segments measuring 2-3 mm long were cut from proximal to distal regions. These segments were fixed and preserved in formalin acetic alcohol (FAA), then transferred to 70\% ethanol (Johansen 1940). Using a hand microtome in Ain Shams University, Egypt, sections $(10-20 \mu \mathrm{m})$ were obtained and double stained with safranin (1\% solution in $50 \%$ ethanol) and light green (1\% solution in absolute ethanol and clove oil) (Corgan and Widmoyer 1971). These sections were photographed using an Olympus photomicroscope, Model CH3ORF200, Japan at Public Service Center of Biological Control, Faculty of Agriculture, Suez Canal University. 
Table 1. The classification, uses and distribution of the studied 15 papilionoid species according to ElHadidi and Boulos (1979), Lock (1989) and Lewis et al. (2005).

\begin{tabular}{|c|c|c|c|}
\hline Tribe & Species & Use & Distribution \\
\hline \multirow[t]{4}{*}{ Dalbergieae } & $\begin{array}{l}\text { Dalbergia lanceolaria L.f. subsp. } \\
\text { paniculata (Roxb.) Thoth. } \\
\text { [Syn: D. paniculata Roxb.] }\end{array}$ & Ornamental & Africa \\
\hline & D. sissoo Roxb. ex DC. & Fodder \& timber & Africa \& Asia \\
\hline & Pterocarpus indicus Willd. & Ornamental & Africa \& Asia \\
\hline & $\begin{array}{l}\text { Tipuana tipu (Benth.) Kuntze } \\
\text { [Syn: Machaerium tipu Benth.] }\end{array}$ & Ornamental & Africa \& South America \\
\hline \multirow[t]{4}{*}{ Millettieae } & $\begin{array}{l}\text { Bolusanthus speciosus (Bolus) } \\
\text { Harms [Syn: Lonchocarpus } \\
\text { speciosus Bolus] }\end{array}$ & Ornamental & Zaire (Africa) \\
\hline & Pongamia pinnata (L.) Pierre & Ornamental & Africa \& Asia \\
\hline & Derris elliptica (Wallich) Benth. & Ornamental & Africa \\
\hline & D. robusta (Roxb. ex DC.) Benth. & Ornamental & Africa \\
\hline \multirow[t]{3}{*}{ Phaseoleae } & Cajanus cajan (L.) Millsp. & $\begin{array}{l}\text { Human food \& } \\
\text { fodder }\end{array}$ & Africa \\
\hline & $\begin{array}{l}\text { Erythrina variegata L. [Syn: E. } \\
\text { indica Lam.] }\end{array}$ & Ornamental & $\begin{array}{l}\text { Africa, Asia, and Indian \& } \\
\text { Pacific Oceans }\end{array}$ \\
\hline & Glycine sinensis Sims. & Ornamental & Africa \\
\hline Sesbanieae & $\begin{array}{l}\text { Sesbania sesban (L.) Fawc. \& } \\
\text { Rendle }\end{array}$ & $\begin{array}{l}\text { Fibre, fodder, } \\
\text { medicinal \& } \\
\text { ornamental }\end{array}$ & Africa \& Asia \\
\hline \multirow[t]{3}{*}{ Sophoreae } & $\begin{array}{l}\text { Sophora davidii (Franchet) Skeels } \\
\text { [Syn: S. viciifolia Salisbury] }\end{array}$ & Ornamental & $\begin{array}{l}\text { Kenya, South Africa (Africa) } \\
\text { \& Asia }\end{array}$ \\
\hline & $\begin{array}{l}\text { S. japonica L. [Syn: Styphnolobium } \\
\text { japonicum (L.) Schott] }\end{array}$ & $\begin{array}{l}\text { Medicinal \& } \\
\text { ornamental }\end{array}$ & $\begin{array}{l}\text { Egypt, Kenya, South Africa, } \\
\text { Zimbabwe (Africa) \& Asia }\end{array}$ \\
\hline & $\begin{array}{l}\text { S. secundiflora (Gomez-Ortega) } \\
\text { Lag. ex DC. }\end{array}$ & Ornamental & $\begin{array}{l}\text { Kenya (Africa), Central \& } \\
\text { North America }\end{array}$ \\
\hline
\end{tabular}

\section{Results and Discussion}

Some recognizable variations as well as similarities were observed among the studied 15 papilionoid species in terms of 18 anatomical characters as summarized in Tables 2 \& 3 and illustrated in Figs. 1-5. In the following sections only the salient features, features showing micro-variations within a category of a character state and the importance of these features in taxonomy are discussed in detail under two broad headings.

\section{Non-vascular features}

Some features, namely epidermal cells shape, cortex structure, pith, crystal type, mucilage elements showed some specific variations among the studied species. The results of petiole outline agree with those of Shaheen $(2006,2007)$ who reported the usefulness of this character in the assessment of the identification of some species of 
Table 2. The characters (non-vascular) of the petiole anatomy of the studied 15 species of Papilionoideae.

\begin{tabular}{|c|c|c|c|c|c|c|c|c|c|c|}
\hline $\begin{array}{l}\text { Characters } \rightarrow \\
\text { Species } \downarrow\end{array}$ & Figure & $\begin{array}{c}\text { Outline (ridges } \\
\& \text { adaxial } \\
\text { groove) }\end{array}$ & $\begin{array}{l}\text { Epidermal } \\
\text { cells }\end{array}$ & Cortex & $\begin{array}{l}\text { Pericyclic } \\
\text { fibres }\end{array}$ & Pith & $\begin{array}{l}\text { Crystal } \\
\text { type }\end{array}$ & $\begin{array}{l}\text { Secretory } \\
\text { elements }\end{array}$ & $\begin{array}{l}\text { Mucilage } \\
\text { elements }\end{array}$ & $\begin{array}{c}\text { Multicellular } \\
\text { trichomes }\end{array}$ \\
\hline Dalbergia lanceolaria & Figs. 1a-c & 1 & 1 & 1 & 2 & 1 & 3 & 0 & 2 & 0 \\
\hline Dalbergia sissoo & Figs. 1d-f & 1 & 3 & 1 & 1 & 2 & 3 & 0 & 2 & 1 \\
\hline Pterocarpus indicus & Figs. 1g-i & 2 & 1 & 1 & 3 & 2 & 3 & 0 & 2 & 1 \\
\hline Тіриапа tipu & Figs. 2a-c & 2 & 3 & 1 & 2 & 1 & 3 & 0 & 1 & 1 \\
\hline Bolusanthus speciosus & Figs. 2d-f & 2 & 2 & 3 & 2 & 3 & 1 & 1 & 0 & 1 \\
\hline Pongamia pinnata & Figs. 2g-i & 2 & 1 & 1 & 2 & 3 & 4 & 1 & 2 & 1 \\
\hline Derris elliptica & Figs. 3a-c & $\begin{array}{l}2 \text { (circular to } \\
\text { rectangular) }\end{array}$ & 1 & 1 & $\begin{array}{l}2 \text { (proximal) } \\
\text { \& } 4 \text { (medial, } \\
\text { distal) }\end{array}$ & $\begin{array}{l}3 \text { (hollow } \\
\text { center) }\end{array}$ & 4 & 1 & 2 & 0 \\
\hline Derris robusta & Figs. 3d-f & $\begin{array}{l}2 \text { (circular to } \\
\text { oblong) }\end{array}$ & 3 & 1 & $\begin{array}{l}2 \text { (proximal) } \\
\text { \& } 4 \text { (medial, } \\
\text { distal) }\end{array}$ & 3 & 4 & 1 & 1 & 0 \\
\hline Cajanus cajan & Figs. 3g-i & 3 & 2 & 2 & 2 & 4 & 4 & 0 & 1 & 1 \\
\hline Erythrina variegata & Figs. 4a-c & 1 & 1 & 1 & 1 (small) & $\begin{array}{c}1 \text { (solid to } \\
\text { hollow center) }\end{array}$ & 2 & 0 & 2 & 0 \\
\hline Glycine sinensis & Figs. 4d-f & $\begin{array}{l}2 \text { (circular to } \\
\text { obtriangular) }\end{array}$ & 1 & 3 & 2 & $\begin{array}{c}3 \text { (solid to } \\
\text { hollow center) }\end{array}$ & 4 & 0 & 1 & 1 \\
\hline Sesbania sesban & Figs. 4g-i & $\begin{array}{l}2 \text { (circular to } \\
\text { oblong) }\end{array}$ & 1 & 3 & $\begin{array}{l}3 \text { (proximal) } \\
\& 1 \text { (medial, } \\
\text { distal) }\end{array}$ & 2 & 3 & 0 & 2 & 0 \\
\hline Sophora davidii & Figs. 5a-c & 1 & 1 & 2 & 2 & 4 & 3 & 0 & 2 & 1 \\
\hline Sophora japonica & Figs. 5d-f & 2 & 3 & 1 & $\begin{array}{l}2 \text { (proximal) } \\
\text { \& } 4 \text { (medial, } \\
\text { distal) }\end{array}$ & 2 & 4 & 0 & 0 & 0 \\
\hline Sophora secundiflora & Figs. 5g-i & $\begin{array}{l}2 \text { (circular with } \\
\text { small ridge } \\
\text { adaxially) }\end{array}$ & 2 & 1 & 2 & 2 & 4 & 0 & 0 & 1 \\
\hline
\end{tabular}

Key to attributes: Outline: $1=$ wavy circular, $2=$ wavy circular with two ridges and a shallow to deep adaxial groove, $3=$ angular to five angled with five angles in between them five furrows. Epidermal cells: 1= tangentially elongated, $2=$ radially elongated, $3=$ tangentially elongated and radially elongated. Cortex: $1=$ large isodiametric parenchyma cells, $2=$ large irregular parenchyma cells, $3=$ outer chlorenchyma and inner parenchyma cells especially in the medial and distal regions. Pericyclic fibers: $1=$ isolated strands, $2=$ a dissected ring, $3=$ continuous layers, $4=$ a continuous ring. Pith: $1=$ large isodiametric parenchyma cells, $2=$ small isodiametric parenchyma cells, $3=$ large and small isodiametric parenchyma cells, 4= large irregular parenchyma cells. Crystal types: $1=$ numerous druses and rhombohedral solitary, $2=$ numerous rod-shaped solitary, $3=$ few to numerous rhombohedral solitary, $4=$ numerous rhombohedral and rod-shaped solitary. Secretory elements: $1=$ present, $0=$ absent. Mucilage elements: $1=$ numerous brown mucilage cavities in the cortical, phloem and pith parenchyma cells, $2=$ brown mucilage cells present in epidermis, cortical, phloem and pith parenchyma cells, $0=$ absent. Multicellular trichomes: $1=$ present, $0=$ absent. 
Table 3. The characters of the petiole vasculature of the studied 15 species of Papilionoideae (v. b. = vascular bundles).

\begin{tabular}{|c|c|c|c|c|c|c|c|c|c|c|}
\hline \multirow{3}{*}{$\begin{array}{l}\text { Characters } \rightarrow \\
\text { Species } \downarrow\end{array}$} & \multirow{3}{*}{ Figure } & \multicolumn{5}{|c|}{ Main petiolar vasculature } & \multirow{3}{*}{$\begin{array}{l}\text { Presence } \\
\text { of ridge } \\
\text { v. b. }\end{array}$} & \multirow{3}{*}{$\begin{array}{l}\text { No. of } \\
\text { ridge } \\
\text { v. b. }\end{array}$} & \multirow{3}{*}{$\begin{array}{l}\text { Separation } \\
\text { of ridge } \\
\text { v. b. }\end{array}$} & \multirow{3}{*}{$\begin{array}{l}\text { Number of } \\
\text { additional } \\
\text { accessory v. b. }\end{array}$} \\
\hline & & \multirow{2}{*}{ Type } & \multicolumn{2}{|r|}{ Shape } & \multirow{2}{*}{$\begin{array}{c}\text { V.b. } \\
\text { division }\end{array}$} & \multirow[t]{2}{*}{ Changes } & & & & \\
\hline & & & In proximal & In medial \& distal & & & & & & \\
\hline Dalbergia lanceolaria & Figs. 1a-c & 2 & 1 & 1 & 3 & 2 & 0 & 0 & 0 & 0 \\
\hline Dalbergia sissoo & Figs. 1d-f & 2 & 3 & 3 (8-10 v.b.) & 1 (1-3 v.b.) & 2 & 0 & 0 & 0 & 0 \\
\hline Pterocarpus indicus & Figs. 1g-i & 1 & 6 & 5 & 4 & 1 & 3 & 1 & 2 & 0 \\
\hline Tipuana tipu & Figs. 2a-c & 3 & 7 & $\begin{array}{c}2 \text { (flat abaxially in } \\
\text { distal) }\end{array}$ & 1 (2-6 v.b.) & 3 & 1 & 2 & 2 & 0 \\
\hline Bolusanthus speciosus & Figs. 2d-f & 3 & 5 & $\begin{array}{l}2 \text { (invaginated } \\
\text { towards pith } \\
\text { adaxially) }\end{array}$ & 2 (2 v.b.) & 3 & 2 & 1 & 2 & 0 \\
\hline Pongamia pinnata & Figs. 2g-i & 3 & 5 & 4 & 1 & 3 & 2 & 1 & 2 & 0 \\
\hline Derris elliptica & Figs. 3a-c & 3 & 5 & 1 (nearly square) & 2 & 3 & 1 & 1 & 2 & 0 \\
\hline Derris robusta & Figs. 3d-f & 3 & 5 & 2 & 1 & 3 & 0 & 0 & 0 & 2 \\
\hline Cajanus cajan & Figs. 3g-i & 3 & 4 & 4 & 2 (1 v.b.) & 2 & 1 & 1 & 2 & 0 \\
\hline Erythrina variegata & Figs. 4a-c & 2 & 3 & 3 (12 v.b.) & 4 & 1 & 0 & 0 & 0 & 0 \\
\hline Glycine sinensis & Figs. 4d-f & 3 & 4 & 4 & 1 (6-7 v.b.) & 3 & 1 & 1 & 2 & 0 \\
\hline Sesbania sesban & Figs. 4g-i & 3 & 6 & 3 (5-8 v.b.) & 1 (3-4 v.b.) & 3 & 2 & 1 & 2 & 0 \\
\hline Sophora davidii & Figs. 5a-c & 2 & 1 & 1 & 3 & 2 & 0 & 0 & 0 & 0 \\
\hline Sophora japonica & Figs. 5d-f & 2 & 1 & $\begin{array}{c}1 \text { (medial) } \& 2 \\
\quad \text { distal) }\end{array}$ & 3 & 2 & 0 & 0 & 0 & 2 \\
\hline Sophora secundiflora & Figs. 5g-i & 2 & 2 & $\begin{array}{l}2 \text { (abaxially } \\
\text { compressed) }\end{array}$ & 3 & 3 & 1 & 3 & 1 & 0 \\
\hline
\end{tabular}

Key to attributes: Main petiolar vasculature type: $1=$ open, $2=$ closed, $3=$ open in the proximal region and closed in the medial and distal regions. Main petiolar vasculature shape in the proximal region: $1=$ excentric cylindrical amphiphloic siphonostele, $2=$ two closely neighbouring amphiphloic siphonosteles, $3=$ circular dictyostele, $4=$ wavy fiveangled dictyostele, $5=$ continuous bicollateral cup-shape, U-shaped, or O-shaped, $6=$ small bicollateral arc, $7=$ Large bicollateral flask-shaped. Main petiolar vasculature shape in the medial and distal regions: $1=$ excentric cylindrical amphiphloic siphonostele, $2=$ wavy angular amphiphloic siphonostele, $3=$ circular dictyostele, $4=$ wavy dictyostele, $5=$ small bicollateral arc. Main petiolar v.b. division: 1= number of bundles increased laterally and abaxially, 2= number of bundles increased adaxially, 3= xylem division only, 4= unchanged bundles. Main petiolar vasculature changes: $1=$ no changes, $2=$ minor changes, $3=$ major changes. Presence of ridge bundles: $1=$ in the three regions of the petioles, $2=$ only in the medial and distal regions, $3=$ only in distal regions, $0=$ absent. No. of ridge v. $b .: 1=$ constantly 2 ( 1 at each ridge side), $2=4$ bundles $(2$ at each ridge side), $3=5-6$ bundles, $0=$ absent. Separation of ridge v.b.: $1=$ from the adaxial sides of the two vascular rings, $2=$ from both ends of the open main trace, $0=$ absent. Number of additional accessory $v$. $b .: 0=$ absent, $2=$ presence of two bundles. 
mimosoid and caesalpinioid species. Metcalfe and Chalk (1983) also listed the presence of mucilage cavities and cells in primary cortex, phloem or pith of the species of the family Fabaceae. Our findings match their records.
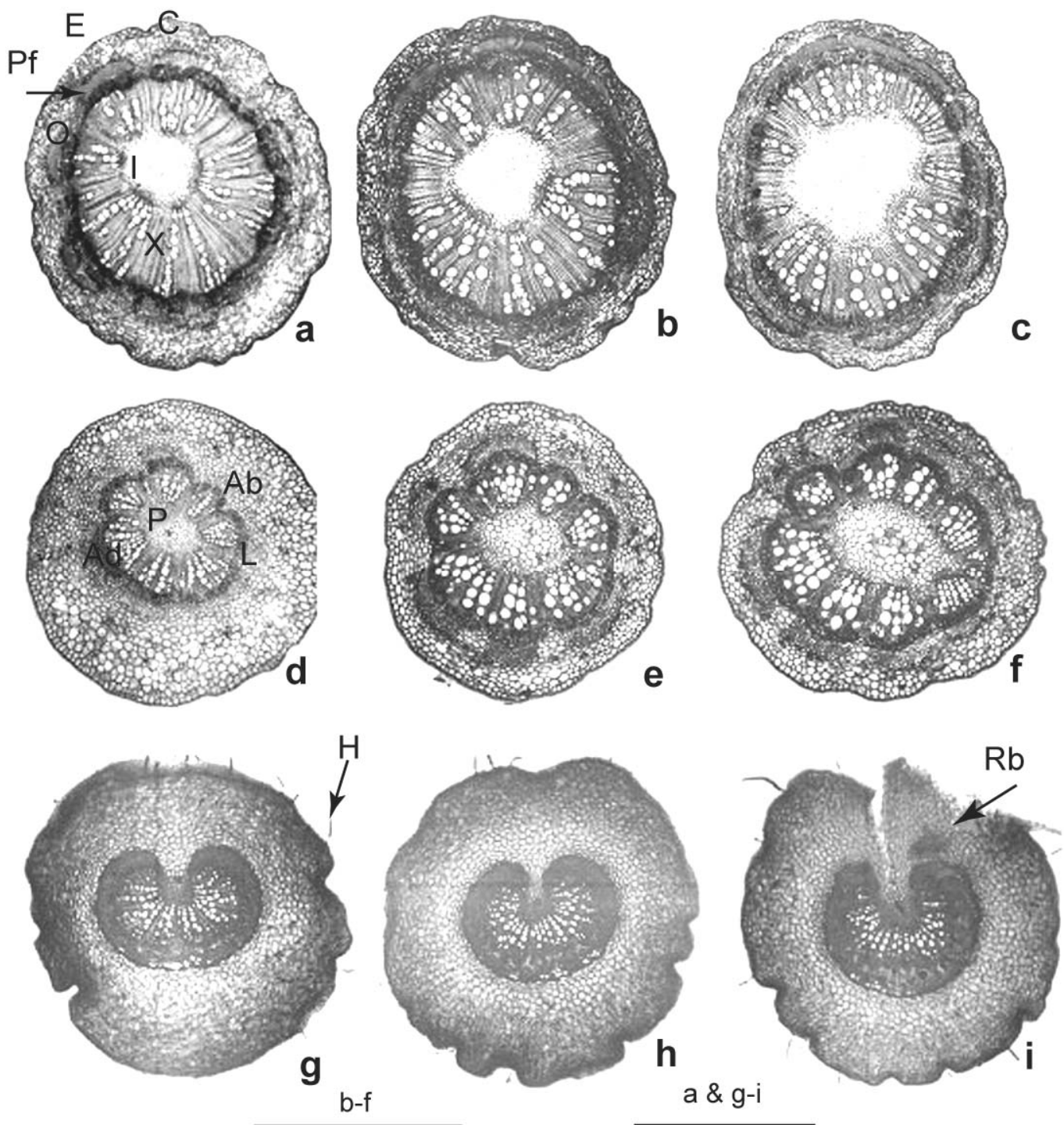

Figs. 1a-i. Cross-sections of the proximal (a, d, g), medial (b, e, h) and distal (c, f, i) regions of the petiole: a-c. Dalbergia lanceolaria subsp. paniculata, d-f. Dalbergia sissoo, g-i. Pterocarpus indicus (tribe Dalbergieae). $\mathrm{Ab}=$ Abaxial bundles, $\mathrm{Ad}=$ Adaxial bundles, $\mathrm{C}=$ Cortex, $\mathrm{E}=$ Epidermis, $\mathrm{H}=$ Multicellar hairs, $\mathrm{I}=$ Inner phloem, $\mathrm{L}=$ Lateral bundles, $\mathrm{O}=$ Outer phloem, $\mathrm{P}=$ Pith, $\mathrm{Pf}=$ Pericyclic fibers, $\mathrm{Rb}=$ Ridge bundles, $\mathrm{X}=$ Xylem. $($ Bar $=1 \mathrm{~mm})$ 
Pericyclic fiber forms: The main petiolar vascular supply is strongly supported by the pericyclic fibers outside the outer phloem in all examined species. These patterns appear to be a diagnostic character between the studied species (Table 2). Generally, the characters of pericyclic sclerenchyma in the petioles are diagnostic to Pterocarpus indicus, Bolusanthus speciosus, Pongamia pinnata, Derris elliptica, D. robusta and Sophora japonica. In this respect, the presence or absence of pericyclic sclerenchyma in woody plants appears to have taxonomic value (Petit 1887). Metcalfe (1983) mentioned that phloem fibers are of considerable taxonomic importance. Ibrahim (1996) reported that a continuous ring of sclerenchyma cells surrounds the main petiolar vasculature in 27 species of subfamily Caesalpinioideae, and the remaining species have either a dissecting ring or isolated strands.

Crystal type: Crystal is a characteristic of Bolusanthus speciosus (numerous druses and rhombohedral solitary crystals) and Erythrina variegata (numerous rod-shaped solitary crystals). In this respect, Metcalfe and Chalk (1950) reported the presence of rodshaped solitary crystals (styloids) in the palisade tissue of Derris, Pongamia and Sophora species. Also, Ibrahim (1996) recorded the presence of druses in 11 species, solitary crystals in 10 species, solitary and druses crystals in 6 species, and crystals absent in 6 species of subfamily Caesalpinioideae.

Secretory elements: These elements are restricted to the cortical region of the petiole of Bolusanthus speciosus, Derris elliptica (small in these two species), Pongamia pinnata and Derris robusta (large in these two species, Figs. $2 \mathrm{~g} \& 3 \mathrm{~d}$ ) of tribe Millettieae. Each secretory element is formed of a large intercellular space surrounded by a layer of tangentially flattened papillose epithelial cells. Earlier, Metcalfe (1983) recorded the presence of these secretory elements in Bolusanthus species (Papilionoideae), and their presence is of diagnostic rather than of taxonomic value.

Multicellular trichomes: Sparsely distributed multicellular-uniseriate trichomes were found in nine studied species (Table 2). In Bolusanthus speciosus and Cajanus cajan these are, however, dense and long (Figs. 2d-f \& 3g-i). Shaheen $(2006,2007)$ also showed trichomes seemed to be of taxonomic interest for the distinction of some of mimosoid and caesalpinioid species.

\section{Vascular bundle features}

Some features, namely tendency of bundles to divide in the main petiole vasculature, changes within the petiole of the same species, presence of ridge (secondary) vascular bundles, number of ridge vascular bundles and separation of ridge bundles are summarized in Table 3. However, a few features need detailed discussion as illustrated below.

Main petiole vasculature type: Within the taxa studied, petiole vasculature type (Table 3) seems to be diagnostic to the two Dalbergia species, Pterocarpus indicus, 
Erythrina variegata and Sophora davidii. In addition, the unique type of petiole vasculature in Bolusanthus speciosus and Pongamia pinnata may support a close relationship between them belonging to tribe Millettieae. In this respect, De Candolle (1879) proposed two types of petiole vasculature: open - where the bundles are arranged in an arc, and closed - where the bundles form circular comparable to that of the stem. His proposals were incorporated in the work of Metcalfe and Chalk (1950).
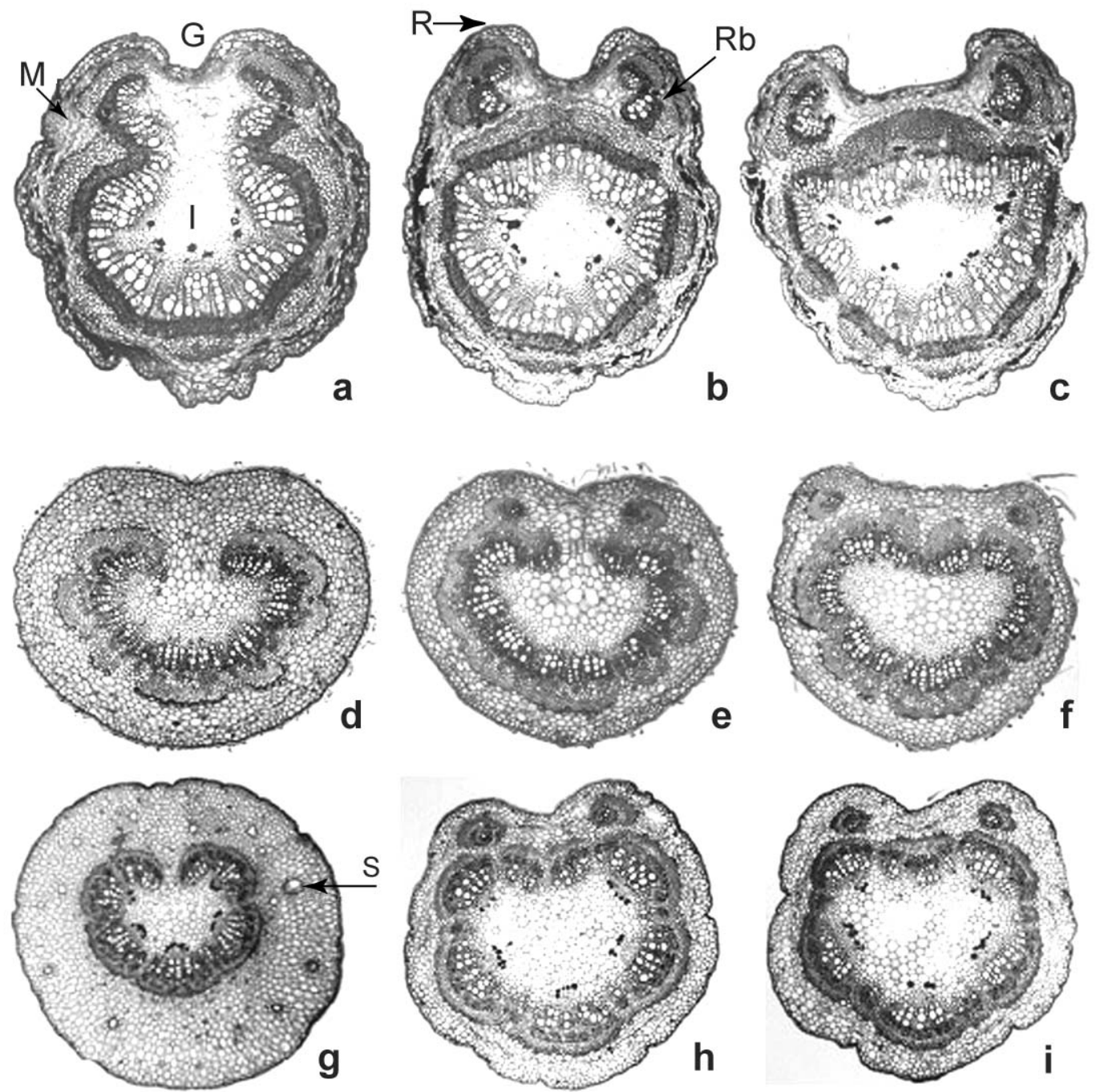

a-f \& h-i

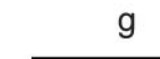

Figs. 2a-i. Cross-sections of the proximal (a, d, g), medial (b, e, h) and distal (c, f, i) regions of the petiole: a-c. Tipuana tipu (tribe Dalbergieae), d-f. Bolusanthus speciosus, g-i. Pongamia pinnata (tribe Millettieae). $\mathrm{G}=$ Adaxial groove, $\mathrm{I}=$ Inner phloem, $\mathrm{M}=$ Brown mucilage elements, $\mathrm{R}=$ Ridges, $\mathrm{Rb}=$ Ridge bundles, $\mathrm{S}=$ Secretory elements. $($ Bar $=1 \mathrm{~mm})$ 
Tendency for the bundles to divide: The increased number of vascular bundles in the medial and distal regions than the proximal one of the petioles (Table 3) seems to be a diagnostic feature of Dalbergia sissoo, Tipuana tipu and Cajanus cajan. In addition, the unique pattern of bundle division in Dalbergia sissoo and Tipuana tipu account for the close relationship between them belonging to tribe Dalbergieae, similar relationship was seen in Derris elliptica and Bolusanthus speciosus belonging to tribe Millettieae. These results agree with those of Shaheen $(2006,2007)$ who reported the importance of this character in the assessment of the identification and delimitation of some mimosoid and caesalpinioid species.

Changes in vascular bundles from proximal to distal region: Three cases of change are recorded from proximal to distal region (Table 3). The main petiolar vascular supply has many variations in types, shapes and tendency of its bundles to divide from the proximal to distal regions. It is diagnostic to Dalbergia lanceolaria (large amphiphloic siphonostele), Dalbergia sissoo (small dictyostele of 7 bicollateral bundles), Sophora japonica, S. davidii (amphiphloic siphonostele) and S. secundiflora (an abnormal structure of two closely neighbouring amphiphloic siphonosteles; one much bigger than the other). The complexity in the structure of the petiole vasculature is also recorded in Faidherbia albida (Shaheen 1995) and in Quercus (Maria and Rodriigo 2003). In contrast, Shaheen $(2006,2007)$ reported the importance of that character in the assessment of the identification of some mimosoid and caesalpinioid species. In this respect, homogeneously in the structure of the petiole vasculature is also recorded in Acacia phyllodes and Acacia podalyriifolia (Duarte and Wolf 2005) and in some caesalpinioid species (Shaheen 2007).

Main petiole vasculature shape in the proximal region: The shape, number and topography vary greatly within the petiole of the same species and between the studied species (Table 3). In the proximal region, seven types were seen:

1) excentric cylindrical amphiphloic siphonostele, in Dalbergia lanceolaria, Sophora davidii and S. japonica (Figs. 1a, 5a, d).

2) two closely neighbouring amphiphloic siphonosteles (one much bigger than the other, in Sophora secundiflora) (Fig. 5g).

3) circular, dictyostele, in Dalbergia sissoo (small, excentric of 7 bundles; three adaxial, two lateral and two abaxial, Fig. 1d) and Erythrina variegata (large of 12 small bundles; three adaxial, six lateral and three abaxial, Fig. 4a).

4) wavy five angled dictyostele, in Cajanus cajan (9 bundles of one abaxial and 8 laterals; four big and four small in between, Fig. 3g) and Glycine sinensis (5 bundles of one big abaxial and four laterals two big and two small, Fig. 4d). 
5) continuous bicollateral cup-shape with two incurved ends adaxially, in Bolusanthus speciosus (Fig. 2d), Pongamia pinnata (Fig. 2g), Derris elliptica (U-shaped, Fig. 3a) and Derris robusta (open O-shaped of small 5 bundles; four laterals and one abaxial, Fig. 3d).
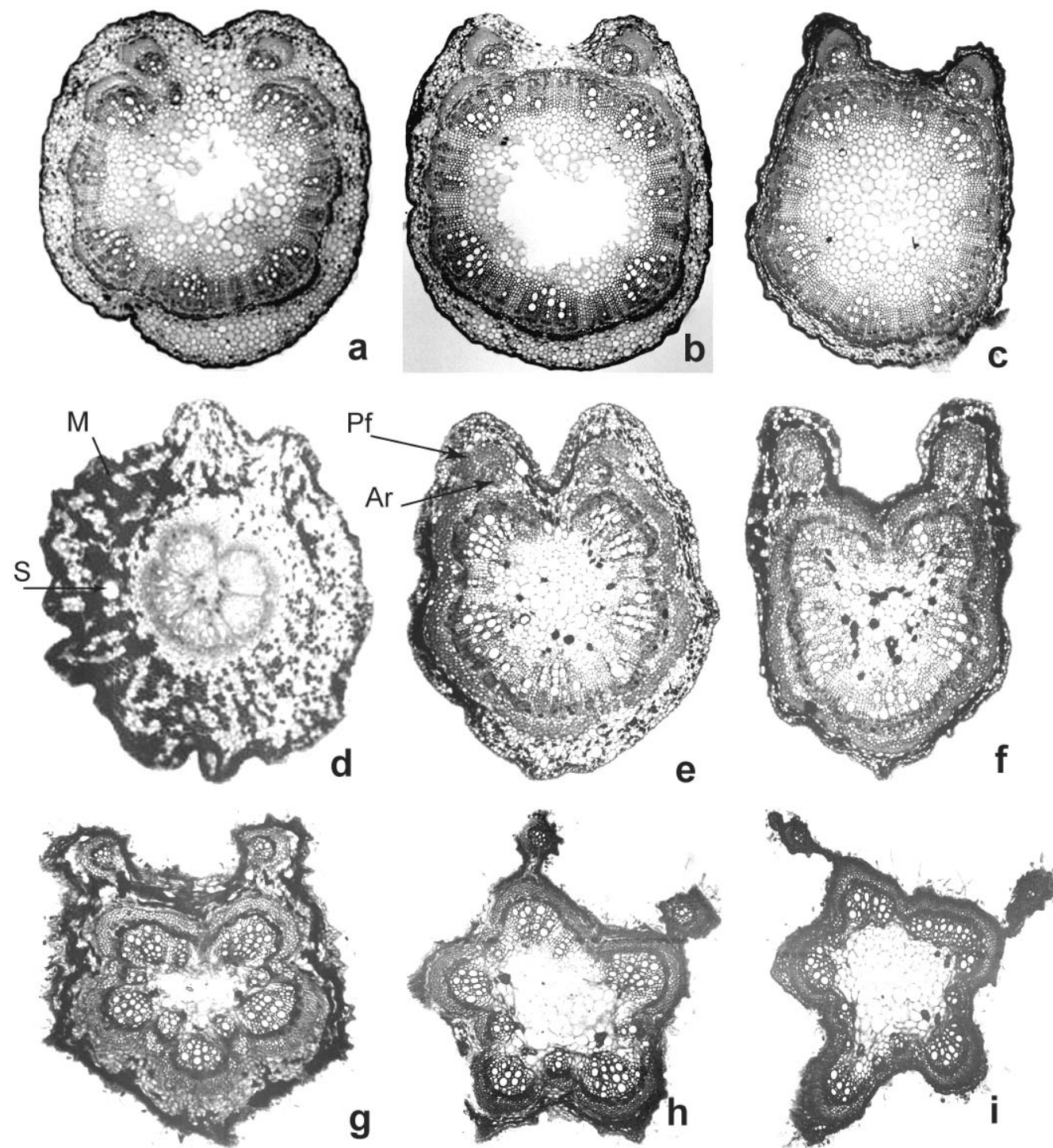

a \& d

b-c

e-i

Figs. 3a-i. Cross-sections of the proximal (a, d, g), medial (b, e, h) and distal (c, f, i) regions of the petiole: a-c. Derris elliptica, d-f. Derris robusta (tribe Millettieae), g-i. Cajanus cajan (tribe Phaseoleae). $\mathrm{Ar}=$ additional accessory ridge bundles, $\mathrm{I}=$ Inner phloem, $\mathrm{M}=$ Brown mucilage elements, $\mathrm{Pf}=$ Pericyclic fibers, $\mathrm{S}=$ Secretory elements. $(\mathrm{Bar}=1 \mathrm{~mm})$ 
6) small bicollateral arc in Pterocarpus indicus (continuous, Fig. 1g) and Sesbania sesban (5 bundles, Fig. 4g).

7) large bicollateral flask-shaped; round basal part with five large bundles, and two long incurved ends adaxially separating each end to two ridge bundles in Tipuana tipu (Fig. 2a).
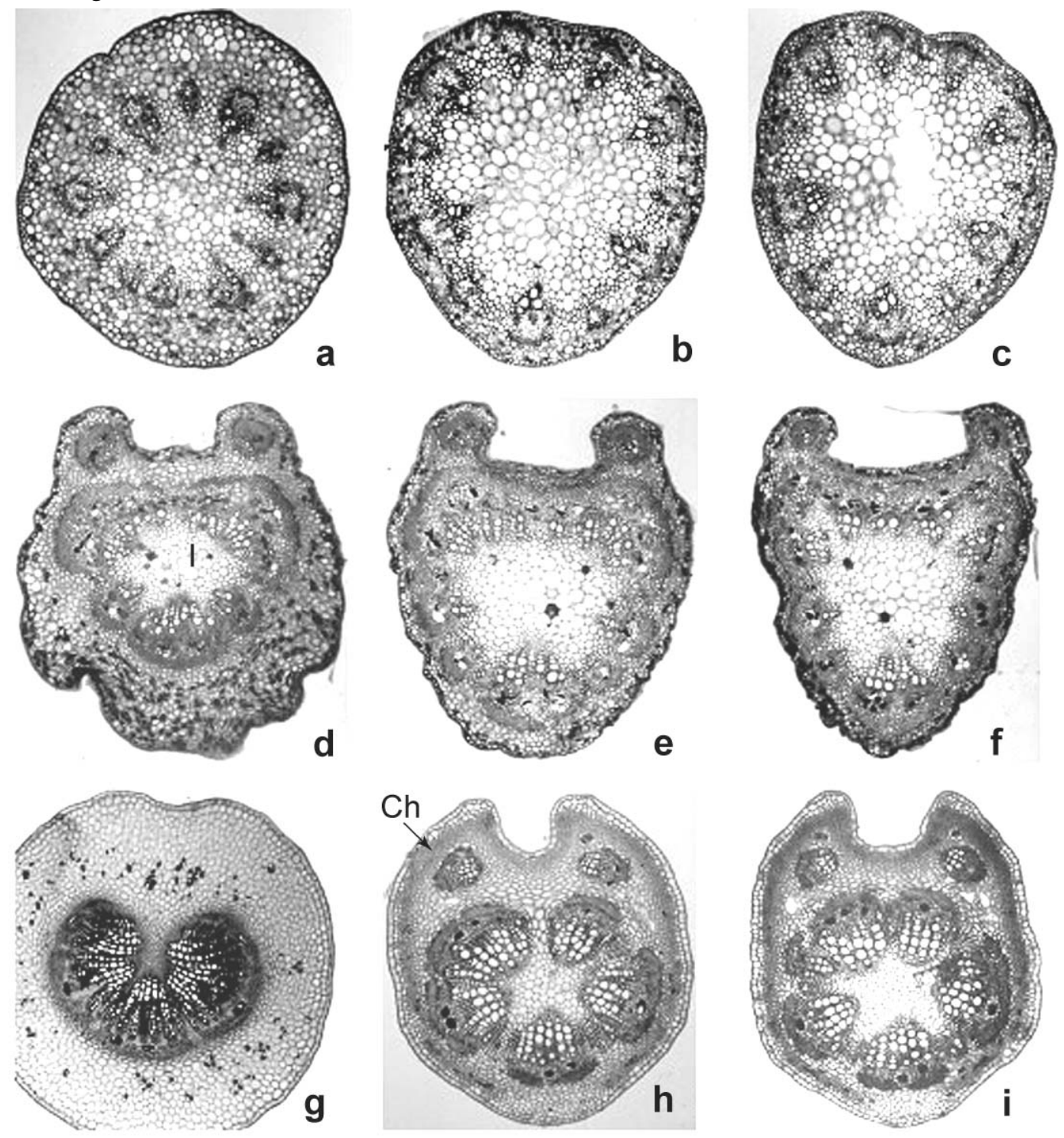

b-f \& i

a \& g-h

Figs. 4a-i. Cross-sections of the proximal (a, d, g), medial (b, e, h) and distal (c, f, i) regions of the petiole: a-c. Erythrina variegata, d-f. Glycine sinensis (tribe Phaseoleae), g-i. Sesbania sesban (tribe Sesbanieae). $\mathrm{Ch}=$ Chlorenchyma cells, $\mathrm{I}=$ Inner phloem. $($ Bar $=1 \mathrm{~mm})$ 

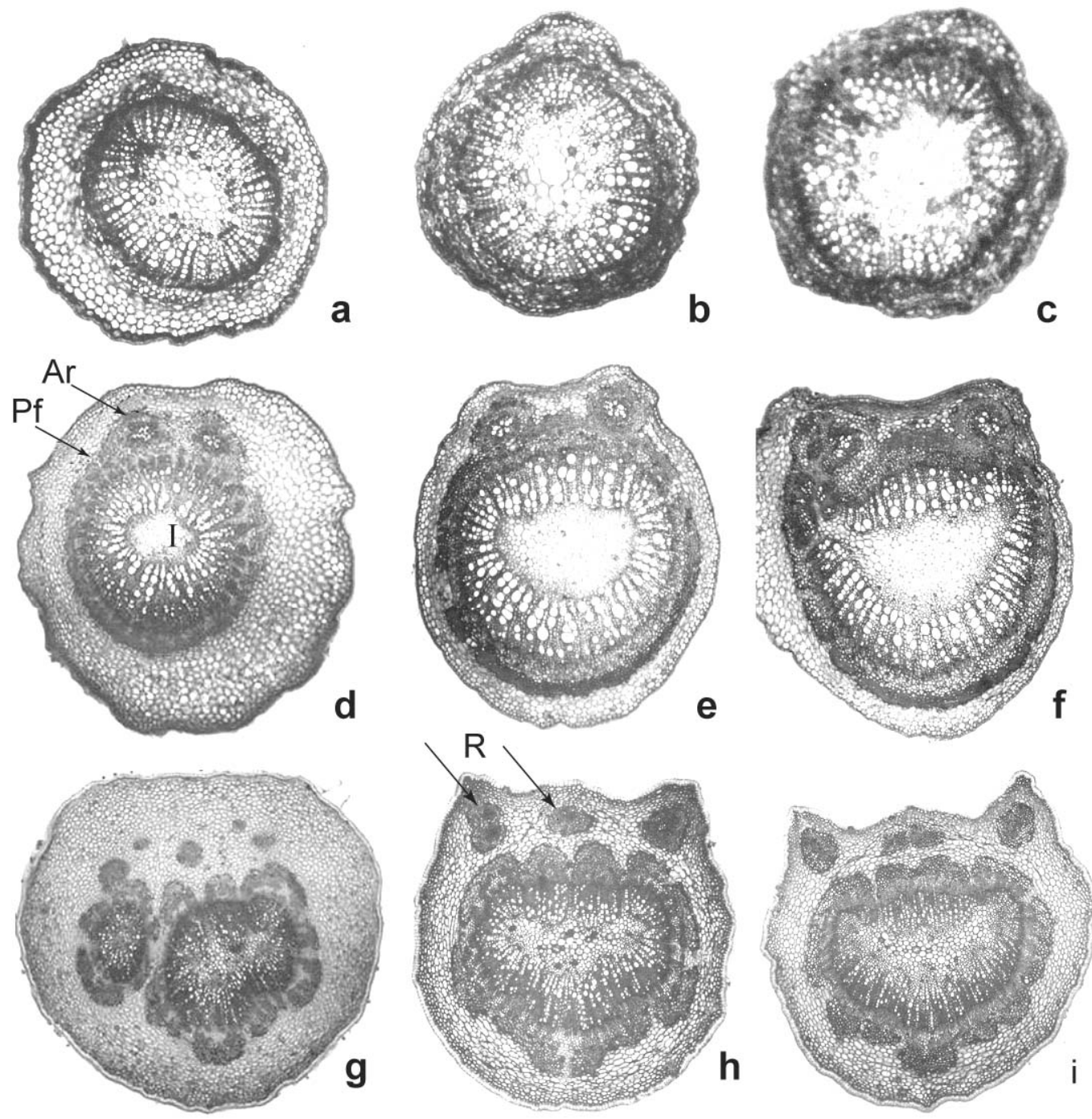

d \& g

h-i

a-c \& e-f

Figs. 5a-i. Cross-sections of the proximal (a, d, g), medial (b, e, h) and distal (c, f, i) regions of the petiole: a-c. Sophora davidii, d-f. S. japonica, g-i. S. secundiflora (tribe Sophoreae). Ar = additional accessory ridge bundles, $\mathrm{I}=$ Inner phloem, $\mathrm{Pf}=$ Pericyclic fibers, $\mathrm{R}=$ Ridge bundles. $($ Bar $=1 \mathrm{~mm})$

Generally, this feature is characteristic to the two species of the two Dalbergia and Derris species, Petrocarpus indicus, Sophora secundiflora, S. javanica and Tipuana tipu. In addition, this result seems to be accounted for the close relationship between Cajanus cajan and Glycine sinensis. In this connection, Hare (1943) and Metcalfe and Chalk (1950) recorded main petiole vasculature strand shape composed of separate bundles or 
continuous in the form of U-shaped, cylindrical or open arc. Ibrahim (1996) also summarized the types of petiole vasculature in the medial regions of the petioles as siphonostele, dictyostele and complete crescent shape.

Main petiole vasculature shape in the medial and distal regions: The major petiole vasculature shapes in the medial and distal regions are tabulated in Table 3. However, the wavy dictyostele show some variations among the species: Pongamia pinnata (fiveangled and invaginated towards pith adaxially, Figs. 2h-i), Cajanus cajan (five-angled with five big bundles lying in the five angles in between them five small bundles lying in the five furrows, Figs. 3h-i) and Glycine sinensis (triangular and invaginated towards pith adaxially, Figs. 4e-f).

Ridge (secondary) vascular bundles: These are situated at the ridges of the adaxial side of the petiole in its cortex with certain taxonomic significance in family Leguminosae (Watari 1934, Ibrahim 1996). There are four cases identified in the present study (Table 3). In case of Pterocarpus indicus, the ridge is present only in the distal region.

Separation of ridge bundles: In terms of the characters of ridge bundles (Table 3), our findings agree with those of Watari (1934) who recorded the presence of the ridge bundles in Pterocarpus indicus, Derris elliptica and Sophora japonica, and their absence in Dalbergia sissoo. In contrast, Watari (1934) reported the presence of the ridge bundles in 53 species of subfamily Papilionoideae, 11 species of Mimosoideae, and 18 species of Caesalpinioideae. Ibrahim (1996) recorded also the presence of the ridge bundles in the medial regions of the petioles of 14 species of Caesalpinioideae.

Additional accessory ridge bundles: There are two such ridge bundles which lie adjacent to the main petiole strand adaxially enclosing with it by a complete ring of pericyclic fibers in Derris robusta and Sophora japonica (Figs. 3e-f \& 5d-f). They separate in the medial region in Derris robusta (Fig. 3e), or in the proximal region in Sophora japonica (Fig. 5d). Shaheen (1995, 2007) reported the presence of the accessary bundles in the core of the main trace in some mimosoid and caesalpinioid species. Ibrahim (1996) recorded also the presence of the additional accessory ridge bundles in the medial regions of the petioles of seven species of subfamily Caesalpinioideae.

In this study, we found major changes in the petiolar supply from proximal to distal regions in the most of the studied species, contrary to Metcalfe and Chalk (1979) who reported that the middle of the petiole is the most reliable position from which a single section can be taken for comparative purposes. Our findings also suggested that petiolar outline shape, the number of ridge bundles (two), crystal type, secretory elements and the unique patterns in the main petiolar vasculature (especially open main vascular type in the proximal regions and closed main vascular type in the medial and distal regions) account for close relationship among the species of tribe Millettieae. 


\section{Acknowledgements}

The authors appreciate the corrections and suggestions of the referees who much contributed to the improvement of this manuscript.

\section{References}

Agbaywa, I.O. and Noukwu, B.C. 2004. The value of morpho-anatomical features in the systematic of Cucurbita species in Nigeria. African J. Biotech. 3(10): 541-546.

Al-Nowaihi, A.S., Khalifa, S.F. and Ishak, I.F. 1980. The significance of comparative anatomy of the petiole in the identification of some Malvaceous taxa. Bull. Fac. Sci. Riyad Univ. 2: 25-41.

Corgan, J.N. and Widmoyer, F.B. 1971. The effect of gibberellic acid on flower differentiation, date of bloom, and flower hardiness of peach. J. Amer. Soc. 96: 54-57.

De Candolle, C. 1879. Anatomie comparée des feuilles de quelques families de dicotylédones. Mém. Soc. Phys. Hist. Nat. Genéve 26: 427-480.

Duarte, M.R. and Wolf, S. 2005. Anatomical characteristics of the phyllode and stem of Acacia podalyriifolia. Revista Brasileira Fermacognusla Brazilion J. of Pharmacognosy 15(1): 71-76.

El-Hadidi, M.N. and Boulos, L. 1979. The Street Trees of Egypt. The American Univ. in Cairo Press, 2nd ed., pp. 1-141.

Ennos, A.I., Spatz, H.Ch. and Speck T.T. 2000. The function morphology of the petiole of the banana, Musa textilis. J. Expt. Bot. 51(353): 2085-2093.

Hare, C.L. 1943. The anatomy of the petiole and its taxonomic value. Proc. Linn. Soc., Lond. 155: 223-229.

Howard, R.A. 1979. The petiole. In: Metcalfe, C.R. and Chalk, L. (eds.), Anatomy of the Dicotyledons: Systematic Anatomy of the Leaf and Stem, with a Brief History of the Subject, 1: 88-96. Clarendon Press, Oxford, UK.

Ibrahim, M.C. 1996. Taxonomic studies on some taxa of Leguminosae-Caesalpinioideae in Egypt. Ph.D. Thesis, Fac. Sci., Ain Shams Univ., pp. 1-293.

Johansen, D.A. 1940. Plant Microtechnique, McGraw-Hill Book Co., New York, pp. 1-523.

Khalifa, S.F. and El Gohary, I.H. 1982. Studies of the Capparidaceae: II. Taxonomic significance of micromorphological attributes of the Cleome species in Egypt. Research Bull., Fac. Agric., Cairo, Egypt, No. 1959.

Lewis, G.P., Schrire, B., Mackinder, B. and Lock, J.M. 2005. Legumes of the World. Royal Botanic Gardens, Kew, pp. xiv+1-577.

Lock, J.M. 1989. Legumes of Africa. A check-list. Royal Botanic Gardens, Kew, pp. 1-619.

Mabberley, D.J. 1997. The Plant-Book: A portable dictionary of the higher plants. Cambridge University Press, Cambridge, 2nd ed., pp. 1-858.

Maria, B.G. and Rodriigo, O. 2003. Leaf anatomy of rubber tree clones. Sci. Agric. 60(4): 709-713.

Metcalfe, C.R. 1983. Secretory structures: cells, cavities, and canals in leaves and stems. In: Metcalfe, C.R. and Chalk, L. (eds.), Anatomy of the Dicotyledons, Wood Structure and Conclusion of the General Introduction, 2nd ed., 2: 64-67. Clarendon Press, Oxford, UK.

Metcalfe, C.R. and Chalk, L. 1950. Anatomy of Dicotyledons, Vol. 1, pp. xiv+1-724. Clarendon Press, Oxford, UK.

Metcalfe, C.R. and Chalk, L. 1979. Anatomy of the Dicotyledons, Systematic Anatomy of Leaf and Stem, with a Brief History of the Subject, 2nd ed., Vol. 1, pp. 1-276. Clarendon Press, Oxford, UK. 
Metcalfe, C.R. and Chalk, L. 1983. Lists of families in which certain diagnostic characters occur, Secretory tissue. In: Metcalfe, C.R. and Chalk, L. (eds.), Anatomy of the Dicotyledons, Wood Structure and Conclusion of the General Introduction, 2nd ed., 2: 222-225. Clarendon Press, Oxford, UK.

Petit, L. 1887. Le pétiole de Dicotylédones au point de vue de l'anatomie comparée et de la taxinomie. Mem. Soc. Sci. Phys. Nat. Bordeaux. Mem. 3: 217-404.

Polhill, R.M. 1981. Papilionoideae. In: Polhill, R.M. and Raven, P.H. (eds.), Advances in Legume Systematics, 2: 191-208.

Saquaro, A. 2005. Leaf morphology and anatomy of the Ficus plant. African J. Biotech. 5(10): 331-346.

Shaheen, A.M. 1995. Morphological and cytogenetical variations in the ecological population of Acacia Mill. in Egypt, Ph.D. Thesis, South Valley Univ., Aswan Fac. Sci., Egypt, pp. 1-163.

Shaheen, A.M. 2006. The value of vascular supply of the petiole trace characteristics in the systematic of some species of subfamily: Mimosoideae-Leguminosae. Asutt J. Bot. 35(2): 193-213.

Shaheen, A.M. 2007. Taxonomic importance of stem-leaf transitional of some species of subfamily: Caesalpinioideae-Leguminosae. Turkish J. Bot. 31(4): 297-310.

Stuessy, F.T. 1990. Plant Taxonomy. The Systematic Evolution of Comparative Data. Columbia University Press, New York, pp. xvii+1-514.

Vesque, J. 1885. Caractères des principales families gamopétales tirés de l'anatomie de la feuille. Annals Sci. Nat. Bot., ser. VII, 1: 183-360.

Watari, S. 1934. Anatomical studies on some leguminous leaves with special reference to the vascular system in petioles and rachises. J. Fac. Sci. Univ. Tokyo Sect. 3-4: 225-365.

(Manuscript received on 19 September 2007; revised on 6 November 2007) 